\title{
A Study of the Countermeasures of the Financial Cooperation under the Framework of "One Belt, One Road" Initiative
}

\author{
Yifang Zhou \\ Economics School \\ Yunnan University of Finance and Economics \\ Kunming, China \\ 356922823@qq.com
}

\author{
Hao Lin* \\ International Business School \\ Yunnan University of Finance and Economics \\ Kunming, China \\ 912719112@qq.com
}

\begin{abstract}
Finance is an important carrier of regional economic integration. Carrying out and deepening international financial cooperation are the prerequisite and guarantee for implementing "One Belt, One Road" initiative and realizing win-win progress of all countries. This thesis on the basis of collaborative aspects of financial markets, institutions, infrastructure and projects financing to analyze regional financial cooperation's actuality and necessity. In the meanwhile, this thesis puts forward some countermeasures and suggestions, which includes that effectively promote the construction of "One Belt, One Road" initiative, strengthen and optimize political communication and coordination mechanism, establish a standardized financial cooperation free trade area, and build a regional financial regulatory cooperation system.
\end{abstract}

Keywords - "One Belt, One Road" initiative; the financial cooperation; the financial innovation

\section{INTRODUCTION}

In September 2013, Chinese president Xi Jinping proposed "One Belt, One Road" initiative that based on the economic cooperation, relied on the key economic and trade industrial park as the cooperation platform. It plans to set up the new Eurasian continental bridge and international economic cooperation corridor to connect Central Asia, South Asia, West Asia with Europe for the purpose of deepening the regional economic integration and sharing common development opportunities. The developing countries are the majority in the countries along "One Belt, One Road" initiative, whose economic development level is relatively low and infrastructure is poor. However, infrastructure investment is an important driving force for stimulating economic growth, and finance is the core tool of the real economy and regional cooperation, which is of great significance to provide financial support for "One Belt, One Road" initiative.

In recent years, the research on financial cooperation under the framework of "One Belt, One Road" initiative has gradually become a hot topic. The existing research results are mainly summarized in the following: necessity, actuality, the existing risks and suggestions. $\mathrm{Li} \mathrm{Ya}$ and Hua Wei [9] analyzed the current situation of financial cooperation in BRICS under the background of financial crisis and pointed out that stable financial cooperation will significantly promote the real economy. Yang Jiuyuan [18] based on the practical results of regional financial cooperation in European, Latin American and east Asia, pointed out that the establishment of the international financial cooperation system effectively reduced the regional financial risks and prevented the accumulation of financial problems. He also expressed that financial cooperation among central Asian countries is an important way to safeguard the economic and energy security. $\mathrm{Xu}$ Yiguo [17] concluded that the optimization and improvement of financial cooperation models is a vital prerequisite for the financialization and systematization of regional economy. Li Wuwei [8] argued that how to use financial cooperation and innovation under the framework of "One Belt, One Road" initiative to provide stable fund is the top issue in deepening international financial cooperation. He also putted forward the future development paths on cooperation is that how to build the regional financial center, establish free trade zones, develop Internet finance, promote the cooperation and innovation of financial products. Wang Min et al [15] proposed that the development of "One Belt, One Road" initiative requires greater government cooperation, policy support and the support from financial institutions and capital. Wei Lei [16] pointed out that the construction of the Silk Road economic belt promoted the financial cooperation and financial openness. It is of greater necessity to propel the facilitation of foreign trade and investment and build a new open economic system. Zhao Qingsong [21] analyzed the actuality and the main problems on financial cooperation in the countries along "One Belt, One Road" initiative, and raised many countermeasures and suggestions in innovating regional financing and guarantee mechanism, playing the leading role of AIIB, speeding up RMB regionalization and internationalization. Ma Boya [10] believed that the insufficient cooperation in construction projects under the framework of "One Belt, One Road" initiative may cause investment and financing risks. Hu Haifeng and Wu Peng [3] proposed that the AIIB would build an international economic cooperation platform to strongly support the construction under the framework of "One Belt, One Road" initiative.

*Corresponding author 
In terms of existing research results, firstly, as for the current situation of China's financial cooperation under the framework of "One Belt, One Road" initiative, with the increasingly close relationship between countries, strengthening the international financial cooperation is the trend. However, the existing article not involved deeply in the necessity of realizing financial cooperation. Secondly, the related research on realizing the financial cooperation in the countries under the framework of "One Belt, One Road" initiative still lacks how to establish a specific financial system and how to build a financial cooperation pattern matching with China in the new period. In conclusion, this paper is devoted to study the countermeasures of financial cooperation in China and explore how to build a strategic system of the regional financial cooperation both adapting to China's development and serving the vision under the framework of "One Belt, One Road" initiative.

\section{ACTUALITY AND NECESSITY}

\section{A. Financial Market Cooperation}

As the people's bank of China taken part in East Asia and the Pacific Ocean central bank governors meeting organization (EMEAP), ASEAN and China, Japan, Korea $(10+3)$ financial cooperation mechanism and other regional cooperation mechanisms, improved China's financial cooperation level in the Asia Pacific region, and made the financial market becoming mature gradually. The sign of bilateral currency swap agreements and bilateral trade currency settlement agreements lay a good foundation for the Chinese Yuan's cross-border trade settlement and direct investment in the countries under the framework of "One Belt, One Road" initiative. It is conductive to maintain bilateral financial stability and promote bilateral trade and investment. As of July 2017, China's central bank has signed a total of 3.3 trillion yuan of bilateral currency swap agreements with 36 central banks or monetary authorities, including Hong Kong, India, Malaysia, Sri Lanka, Tajikistan, Armenia, etc. By the end of 2017, the central bank of China has signed the border trade local currency settlement agreement with the central bank of Laos, Nepal, Russia and Uzbekistan, etc.

\section{B. Financial Institutions and Projects Financing Cooperation}

China vigorously promotes the cooperation of bilateral, multilateral financial institutions and projects financing under the framework of "One Belt, One Road" initiative. At present, having already set up the Asian infrastructure investment bank, BRICS new development bank, Shanghai cooperation organization bank, Asian development bank, the Silk Road fund, China-ASEAN investment cooperation fund, China-CEEC investment cooperation fund, China-Eurasian economic cooperation fund, China-Africa production capacity cooperation fund, etc. In terms of two-way establishment of financial institutions and provision of financing between China and the countries along "One Belt, One Road" initiative, by the end of 2017, 10 Chinese banks had set up 68 first-level branches in 26 countries and regions. Meanwhile, 55 banks in 21 countries along "One Belt, One Road" initiative have set up financial institutions in China. Since China has launched the area initiative, Chinese banks are involved in the area construction projects more than 2600, whose total amount of loan over $\$ 200$ billion in transportation infrastructure, energy resources, equipment manufacturing, exports and so on. In May 2017, Chinese president Xi Jinping in "One Belt, One Road" initiative cooperation summit forum announced that China will add 100 billion yuan to the Silk Road fund. And, China launched the Asian infrastructure investment bank, which has raised $\$ 1.7$ billion for seven projects by far.

\section{Financial Infrastructure Cooperation}

The establishment of RMB cross-border payment system (CIPS) is a significant financial infrastructure that aimed to adapt to the development of cross-border trade and promote the internationalization of RMB. At present, the second phase of CIPS has been put into operation, and 10 Chinese and foreign banks has carried out simultaneously. CIPS operating time covers the working time of all time zones around the world basically to support global payments and financial markets business, meet the RMB business demand of global users. According to the figures from the central bank by the end of 2017, there are more than 250 thousand enterprises and 245 banks launched cross-border RMB business, 195 countries and regions had cross-border RMB business with China. And there was a total amount of nearly 6 trillion yuan in national current account and direct investment cross-border RMB settlement, and the Chinese yuan remains the world's sixth-largest payment currency, accounting for $1.75 \%$. By December 2017, the total amount of RMB financial assets held by overseas institutions and individuals will increase to 4.28 trillion yuan. The total amount of 2017 increased by 125.257 billion yuan compared with 2016, and a year-on-year increase of $41.3 \%$. It was the first time in three years that overseas institutions and individuals have increased their holdings of domestic RMB financial assets. Among them, the market value of stocks held by overseas institutions was 11746.67 billion yuan. The escrow balance of bonds was 11.882 billion yuan. The balance of loans to domestic institutions was 7390.00 billion yuan. The balance of RMB deposits held by non-residents in domestic Banks was 1173.472 billion yuan. By the end of 2017, more than 250,000 enterprises and 245 banks had cross-border RMB business, and 195 countries and regions had cross-border RMB payments with China (Fig. 1.). For example, in 2017, the bank of China had a total of 3.9 trillion yuan of cross-border RMB settlement and the amount of cross-border RMB liquidation up to 350 trillion yuan.

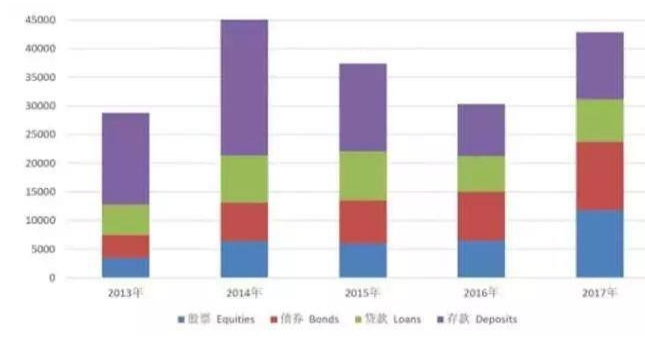

Fig. 1. 2013-2017 overseas institutions and individuals hold domestic RMB financial assets (RMB 100 million) 


\section{CONCLUSION}

The in-depth cooperation in the financial field is an important tool to complete project construction under the framework of "One Belt, One Road" initiative, and the core link of promoting regional economic integration. With "One Belt, One Road" initiative implement steadily, the future financial cooperation system between China and other countries that involved in "One Belt, One Road" initiative will be drive by the Asian infrastructure investment bank and the Silk Road fund. It will become a financial cooperation system that include cross-border trade finance, energy finance and other multiple factors to serve the real economy of the Asia-pacific region and jointly realize regional economic prosperity and development.

\section{A. Strengthening and Improving Communication and Coordination Mechanisms on All Countries' Financial Policies, Establishing a Standardized Free Trade Area for Financial Cooperation}

Under the framework of "One Belt, One Road" initiative, building a smoothly political communication and coordination mechanism is a fundamental guarantee to enhance the level of regional financial cooperation in a win-win way. The countries that involved in "One Belt, One Road" initiative, on the basis of existing bilateral or multilateral financing mechanism, such as AIIB, the Silk Road fund, Asian bond fund and China's sovereign wealth fund, relying on "APEC summit", "EMEAP" and other existing platforms to establish, consolidate and consummate national financial political coordination and cooperation mechanism, finance ministers dialogue meeting and others bilateral and multilateral negotiation mechanisms, promote financial cooperation in infrastructure construction, open-source, industrial investment and so on.

In addition, setting up a standardized free trade area of regional financial cooperation is contributed to build a transparent and normative economic trade financial markets in countries along "One Belt, One Road" initiative, speed up the intergovernmental cooperation and consultation. Meanwhile, signing multi-level bilateral or sub-regional free agreements and investment protection agreements, providing a institutional guarantee for Chinese enterprises to invest and finance and expand trade.

\section{B. Accelerating the Cooperation in the Regional Financial Market under the Framework of "One Belt, One Road" Initiative and Promoting the Internationalization of Chinese Financial Market}

The open financial market is an important part of building and improving the regional financial cooperation system. Expanding the connectivity of capital markets such as China's stock and bond markets will help to accelerate the regional financial markets development. At present, as the gradual development of the offshore RMB international bond business, dim sum bonds in Hong Kong, Singapore lion city bonds, Taiwan island bonds, panda bonds and others offshore RMB bonds business is developing rapidly. RMB qualified foreign institutional investors (RQFII), qualified domestic institutional investors (RQDII), Shanghai-Hongkong stock connection, Shenzhen-Hongkong stock connection, bonds connection and other financial services will be launched successively. RMB internationalization provides all kinds of financial activities and regional financial markets with a cooperation platform. Southeast Asia, South Asia has a close economic relationship with China. Therefore, in the local, RMB internationalization has a good opportunity to expand and improve RMB settlement network and RMB cross-border payment system (CIPS) furtherly.

\section{Deepening Cooperation with the Financial Institutions and Providing Financial Support for Industrial Chains under the Framework of "One Belt, One Road" Initiative.}

International financial cooperation theory stresses that improving the aggregation degree of cross-border capital and institutions can directly promote the regional economic cooperation and development. Therefore, we should actively promote the establishment of branches between China and overseas financial institutions. In financing projects under the framework of "One Belt, One Road" initiative, China's financial institutions should strengthen cooperation with multilateral international financial institutions and financial institutions in the project-host country, such as policy banks, commercial banks, sovereign wealth funds, industrial investment funds, venture capital and so on. And, encouraging bilateral financial institutions under the framework of "One Belt, One Road" initiative to carry out regional financial cooperation, such as cross-regional equity cooperation, syndicated loans, financing agency appropriately, etc. And, we will encourage qualified domestic institutional investors, for instance, insurance companies, social insurance funds and enterprise annuities to participate in investment through expanding the QDII quota and scope, improving foreign exchange management. At the same time, private capital is encouraged to participate in investment by the way of BOT and PE fund, etc. To provide financial support and diversified financial services for the industry chain under the framework of "One Belt, One Road" initiative and improve regional economic integration.

\section{Establishing a Regional Financial Regulatory \\ Cooperation System in the Countries Along "One Belt, One Road" Initiative.}

The "One Belt, One Road" initiative has strengthened regional economic cooperation. The effective and sound regional financial cooperation system is of great importance in ensuring the sustainable development of cooperation. On the one hand, China's financial regulatory agency on the basis of the EMEAP and 10+3 financial cooperation mechanism improved the regional policy coordination and regulatory consistency in regional major issues, and gradually set up efficient supervision coordination mechanism. On the other hand, building efficient regional financial security supervision mechanism jointly to ensure the security and stability of regional finance operation and accurately predict the risk of regional finance. And, we should set up a financial risk warning system and a cooperative mechanism for emergency treatment, also establish a cooperative and exchange mechanism for cross-border risk and crisis management. In terms of improving financial regulation, it is necessary to coordinate the cooperative relationship between relevant 
agencies and the actions of various parties to truly form a partnership of mutual supervision, promotion and cooperation.

\section{E. Promoting the Regional Financial Cooperation under the Framework of "One Belt, One Road" Initiative on the Basis of Financial Innovation}

The long-term development of "One Belt, One Road" initiative is inseparable from innovation. And the regional financial cooperation is also inseparable from financial innovation. In the stage of economic globalization, with the deepening of China's economic system reform, it is necessary to promote regional financial cooperation by financial innovation under the framework of "One Belt, One Road" initiative.

\section{1) Innovation in financial business}

The regional financial cooperation under the framework of "One Belt, One Road" initiative should allocate various financial support reasonably, carry out multiple method drive and expand the capital channel. For example, regional financial institutions should work together, and extensively develop the local bond business, improve trade form, by the way of various cooperation platforms to expand the cooperative way of investment and financing of related business.

\section{2) Innovation in financial institutions}

Financial institutions are the main part of the financial markets. In the digital information age, building efficient and convenient Internet financial institutions, and depending on the Internet platform to realize financial cooperation. And, we should make it easier for financial institutions to get the two-way access and provide more complete cross-border financial service. In addition, with the support of policy in the countries along "One Belt, One Road" initiative, Internet financial platform as the carrier of financial institutions to accelerate the construction of online banking business. The financial institutions by the business of syndicated loans, cross-border mergers and acquisitions loan to increase financial support and build global leading online trading financial services to provide favorable conditions for regional financial cooperation and ensure the long-term implementation of strategy.

\section{3) Innovation in financial markets}

In terms of the innovative mode of financial market, it is necessary to strengthen the construction of regional financial center, optimize institutions and talents, and improve financial services. The regional banks and financial companies should also give full play to the advantage of cooperation and coordination to minimize financial risks. At the same time, signing the related agreements in the countries along "One Belt, One Road" initiative to jointly set up the regional industry development fund, building science and technology industry development zone, establishing fund lending market, which can ensure the vitality of regional economy and the regional financial cooperation.

The regional financial cooperation in the countries along "One Belt, One Road" initiative not only is conducive to improve the quality and scale of national strategic cooperation, become a new power for the balanced development of all countries' relationships, but also to the growth of the global economy. Promoting the regional financial cooperation under "One Belt, One Road" initiative is both the need to deepen China's opening up and the help to strengthen the mutually beneficial cooperation of all countries in the world.

\section{ACKNOWLEDGEMENT}

Here, I want to deeply thank my school and college for providing me the opportunity to express my ideas. Then, I must express my heartfelt gratitude to my master tutor give me much patient and professional guidance during the writing of this thesis. Finally, I would like to thank all those who helped me, without their help, I couldn't finish it.

\section{REFERENCES}

[1] D.K. Das, "China's contribution to recent convergence and integration among the Asian economies," Journal of East Asian Economic Integration, 1st ed., vol.17,2013.

[2] C.L. Hu, "A study of strategic financial support under the framework of 'One Belt, One Road' initiative," Hainan Finance, vol.9, 2015, pp.31-34.

[3] H. F. Hu and P. WU, "The financial power of AIIB helps 'One Belt, One Road' initiative: strategic relationship, challenges and choices," The Journal of Humanities, 1st ed., vol.9, 2016, pp.20-28.

[4] R.N. Jia and N. Wei, "The actuality, problems and suggestions of construction under the framework of financial support 'One Belt, One Road' initiative,” International Trade, 5th ed., vol.9, 2016, pp.43-47.

[5] C. Lin, B. Yang and W. Zhang, "The study of six financial support docking 'One Belt, One Road',' Western Forum, 1st ed., vol.26, Jan. 2016, pp.19-26.

[6] G.B. Liu, "On AIIB's role of financial support in the Belt and Road Initiative," Northeast Asia Forum, vol.6, 2016, pp.58-66.

[7] R. Lundell and S. Bond, "Initial Conditions and Moment Restrictions in Dynamic Panel Data Model," Journal of Econometrics, 1st ed., vol.87, 1998, pp.115-143.

[8] W.W. Li, "Financial cooperation and innovations of the Economic Belt along the Silk Road," Research on the theory of Mao Zedong and Deng Xiaoping, 10th ed., vol.1, 2014, pp.1-8.

[9] Y. Li and W. Hua, "Research on the coordination mechanism of international financial cooperation in BRICS countries," Rural Finance Research, 9th ed., vol.6, Sept., 2011, pp.34-38.

[10] B.Y. Ma, "The prevention of financial risks under the framework of 'One Belt, One Road' initiative," Journal of Party and Government Cadres, vol.6, 2016, pp.50-53.

[11] M. Rellano and S. Bond, "Some Test of Specification for Panel Data: Monte Carlo Evidence and an Application to Employment Equation," Review of Economic Studies, 2nd ed., vol.58, 1991, pp.277-297.

[12] J. Scott and R. Wilkinson, "China threat? Evidence from the WTO," Journal of World Trade, 4th ed., vol.47, 2013, pp.83-91.

[13] D. Wang, "The significance of the AIIB to China and the world," Northeast Asia Forum, vol.3, 2015, pp.48-64.

[14] S.K. Wang, "Giving full play to China's financial soft power to build a three-dimensional financial service system under the framework of 'One Belt, One Road' initiative," International Finance, 8th ed., vol.3,2015.

[15] M. Wang, Q.S. Chai, Y. Wang, R.N. Liu, Q.Y. Zhou, J.Z. Jia, and L.L. Zhang, "The strategic implementation of 'One Belt, One Road' initiative and the strategic concept of international financial support," International Trade, vol.4, 2015, pp.35-44.

[16] L. Wei, "The Silk Road fund promotes the connectivity of 'One Belt, One Road' initiative,” International Business Accounting, vol.4, 2015, pp.57-66. 
[17] Y.G. Xu, "Financial elements in the strategic concept of Silk Road Economic Zone," Banker, vol.10, 2014, pp.56-58.

[18] J.Y. Yang, "The theory and practice of international financial cooperation," Special Zone Economy, vol.6, 2011, pp.92-93.

[19] Z.H. Yang, "Accelerating the comprehensive establishment of 'One Belt, One Road financial+' strategic mechanism," International Economic Cooperation, vol.6, 2015, pp.35-42.

[20] H.L. Zhang, "Financial guidance and 'One Belt, One Road' initiative," Financial forum, vol.4, 2015, pp.8-14.

[21] Q.S. Zhao, "Research on international financial cooperation between China and the countries along 'One Belt, One Road'," Journal of Suzhou Vocational University, 1st ed., vol.27, Mar., 2016, pp.8-12. 